\title{
REPRESENTAÇÕES SOCIAIS DE AGRONEGÓCIOS: UM ESTUDO A PARTIR DA REDE SOCIAL FACEBOOK
}

Social representations of agribusiness: a study from the facebook social network

Representaciones sociales de los agronegocios: un estudio de la red social facebook

\section{Magali Costa Guimarães ${ }^{*}$, Marlon Vinícius Brisola ${ }^{1}$}

${ }^{1}$ Área de Ciências Sociais Aplicadas e Agronegócios, Faculdade de Agronomia e Medicina Veterinária, Universidade de Brasília, Brasil.

*Rua 30-norte, Lote 2, Apto 1504, Águas Claras, Brasilia, DF, Brasil. CEP:71.918-180.

e-mailmagaliguimaraes@unb.br.

\section{Artigo recebido em 27/10/2021 aprovado em 01/06/2021 publicado em 20/10/2021.}

\section{RESUMO}

Investigar as representações sociais sobre o agronegócio a partir de opiniões expressas no Facebook constituiu-se no objetivo central deste estudo. Metodologicamente, sua realização envolveu a análise das reações/comentários de usuários dessa rede social a um post/matéria envolvendo o agronegócio e questões ambientais no Brasil. Os comentários de 93 usuários do Facebook e seguidores de um veículo de comunicação de elevada expressão nacional se constituíram no corpus para análise de conteúdo e análises textuais realizadas por meio do software Iramutec. Os resultados revelaram que as representações sociais sobre o agronegócio são marcadamente polarizadas e associadas a aspectos ideológicos-partidários. De uma maneira geral, os usuários o associam à grande produção agropecuária, revelando o distanciamento da representação social do conceito acadêmico. A implicação dos sujeitos - focalização - na representação foi perceptível, levando à conformação da representação aos interesses dos indivíduos e a uma defesa quase passional de seus pontos de vista.

Palavras-chave: Agronegócio. Representações sociais. Redes sociais

\section{ABSTRACT}

Investigating the social representations about agribusiness from the opinions expressed on Facebook was the central objective of this study. Methodologically, its realization involved the analysis of reactions/comments from users of this social network to a post/article involving agribusiness and environmental issues in Brazil. The comments of 93 Facebook users and followers of a well-known national communication vehicle were the corpus for content analysis and textual analysis carried out using the Iramutec software. The results revealed that social representations about agribusiness are markedly polarized and associated with ideological-partisan aspects. In general, when talking about agribusiness the users associate it with the large agricultural production, revealing the distancing of social representation from the academic concept. The implication of the subjects - focusing - on the representation was visible, leading to the conformation of the representation to the interests of individuals and an almost passionate defense of their points of view.

Keywords: Agribusiness. Social representations. Social networks.

\section{RESUMEN}

Investigar las representaciones sociales sobre los agronegocios desde las opiniones expresadas en Facebook fue el principal objetivo de este estudio. Su realización involucró el análisis de las reacciones / comentarios de los usuarios de esta red social a un post / artículo que involucraba agronegocios y temas ambientales en Brasil. Los comentarios de 93 usuarios de Facebook y seguidores de un vehículo de comunicación de renombre nacional constituyeron el corpus para el análisis de contenido y análisis textual realizado mediante el software Iramutec. Los resultados revelaron que las representaciones sociales sobre los agronegocios están marcadamente polarizadas y asociadas a 
aspectos ideológicos partidistas. En general, los usuarios lo asocian con la gran producción agrícola, revelando el alejamiento de la representación social del concepto académico. La implicación de los sujetos - foco - en la representación fue notoria, conduciendo a la conformación de la representación a los intereses de los individuos ya una defensa casi apasionada de sus puntos de vista.

Descriptores: Agronegocios. Representaciones sociales. Redes sociales..

\section{INTRODUÇÃO}

A expressividade do agronegócio, principalmente em termos econômicos, parece ser responsável por sua percepção positiva no Brasil, aspecto que pode ser facilmente identificado nas publicações de boa parte da mídia brasileira. Há anos, sua participação no Produto Interno Bruto (PIB) vem sendo ressaltada como importante para o equilíbrio na balança comercial brasileira (BRANCO, 2015; CEPEA, 2018; CILO, 2020). Os números governamentais confirmam a pujança do setor, sendo, o Brasil, considerado um global player importante quando se trata de agronegócios (WILKINSON, 2004).

O setor é um impulsionador de economias locais e, socialmente falando, revela-se importante para a melhoria em termos de condições de vida nas pequenas e médias cidades brasileiras. Conforme destacam Gasques et al. (2004, p. 11) “a grande maioria das pequenas cidades brasileiras tem sua economia alicerçada no agronegócio".

Buainain et al. (2014) salientam que a força do desempenho do setor esteve relacionada às inovações tecnológicas e à descentralização da posse da terra, reduzindo sua importância em termos de fator de produção. Essa nova configuração passou a exigir pessoas capazes em lidar com a dinamicidade e especificidades do setor. Em função disso, a demanda por novos profissionais ligados à gestão de agronegócios tornou-se central ao país, e a partir da década de 1990, vê-se o crescimento de cursos destinados a qualificar estes profissionais (CAPPELLESSO; GUIMARÃES, 2016).
Ao mesmo tempo em que o quadro delineado aponta para a importância do agronegócio, enquanto setor produtivo - o que faz dele merecedor investimentos em termos de objeto de investigação científica e de qualificação da força de trabalho aqueles que se qualificam para tal, por vezes, são convocados a justificarem a sua escolha e atuação profissional. Aos poucos passam a compreender o "peso" que esta formação carrega, já que o conceito de agronegócio traz incorporado também elementos contraditórios e de cunho negativo. Muitas vezes percebido como um "inimigo", o agronegócio tem sido associado à degradação do meio ambiente e ao uso intensivo de agrotóxicos (MST, 2015; WELLE, 2014), também é associado ao latifúndio improdutivo (CAUME, 2009), sendo o impacto negativo de sua expansão sobre populações indígenas e comunidades tradicionais também apontado na literatura (FAVARETO, 2019).

Sendo assim, torna-se relevante aprofundar no conhecimento das representações sociais (RS) sobre o agronegócio. Estas, segundo (SÁ, 1993), integram o universo consensual do conhecimento denominado senso comum e, enquanto construção social, não estão separadas das condutas dos indivíduos, influenciando e justificando atitudes e comportamentos. Portanto, essa compreensão se torna essencial para dar conta das contradições que o termo carrega e orientar, em contrapartida, a conduta daqueles que atuam no setor (gestores de organizações que integram diferentes elos de cadeias produtivas do agronegócio, formuladores de políticas públicas, acadêmicos e pesquisadores).

Como esforço nesta compreensão, já foram investigadas as RS sobre o agronegócio de discentes 
de cursos ligados à sua gestão (CAPPELESSO; GUIMARÃES, 2016; CAPPELESSO; GUIMARÃES; CARVALHO, 2019) e em um veículo de comunicação brasileiro (SILVA; GUIMARÃES, 2016). No presente estudo, objetivou-se investigar as RS sobre o agronegócio a partir de opiniões expressas no Facebook, a maior rede social do mundo, com mais de dois bilhões de usuários (CLEMENT, 2019).

Segundo Teixeira e Azevedo (2011), a elevação da importância das redes sociais tem ampliado o número de estudos que se utilizam de informações nelas compartilhadas. Nesse sentido, pesquisas mercadológicas e de opinião têm sido realizadas (KOZINETS, 2002; MARQUES; VIDIGAL, 2018), favorecendo o surgimento de novas metodologias investigativas como a netnografia (KOZINETS, 2002; MESQUITA; MATOS; MACHADO, 2018). Não obstante, as redes sociais também têm despertado o interesse daqueles que se preocupam com os impactos que podem ter na subjetividade, nos comportamentos e nos relacionamentos de seus usuários (CHOW; WAN, 2017; JOO; TENG, 2017; ROSA; SANTOS, 2013), bem como para investigação das representações sociais (RESENDE, 2015).

\section{O Facebook e as Representações Sociais (RS)}

Como constata Castells (2005, p. 26, grifos do autor): "Nós estamos em uma sociedade em rede", onde as formas de comunicação se horizontalizaram, ampliando as possibilidades de comunicação sem a, antes imperiosa, mediação dos canais institucionais e tradicionais. Se a organização da vida social em redes não se trata de algo novo nas sociedades humanas, conforme apontado pelo autor, a novidade diz respeito às tecnologias que dão base às novas redes organizadas no chamado ciberespaço.

Barbosa e Souza (2018, p. 281) definem estas redes sociais digitais como "um conjunto de ferramentas virtuais de fácil utilização e acesso que têm grande abrangência, com características de desterritorialização". Elas conectam os indivíduos por meio de comunidades, de formação de grupos, de páginas e perfis individuais diversos. Por meio delas, os indivíduos se interagem, divertem, se comunicam, se informam ou fazem negócios (MARQUES; VIDIGAL, 2018).

Mundialmente falando, o Facebook é a rede social que possui o maior número de usuários (CLEMENT, 2019). Rosa e Santos (2013) destacam que essa rede é considerada, ao mesmo tempo, a reprodução de uma sociedade global [hiperconectada] e um espaço para livre expressão dos seus usuários. É um espaço virtual de produção de sentidos, assim como a dinâmica da vida social real, onde os sujeitos estão em permanente negociação cotidiana, expressando [ou dissimulando] "sentimentos, pensamentos, ideias, emoções e desejos" (ROSA; SANTOS, 2013, p.178).

Estudando questões relativas à subjetividade e à identidade, os autores supracitados sugerem que na criação de perfis, na exposição e nas interações estabelecidas neste espaço virtual, os sujeitos fazem uso de um "Processo de Negociação de Identidades". Sendo assim, eles se expressam e selecionam os aspectos identitários que desejam publicizar, em função de suas motivações e interesses. Apesar desse processo de negociação, os autores consideram que não necessariamente tudo que se mostra ou se expressa é ilusório ou falso, mas sim, faces identitárias dos sujeitos. Eles acrescentam: "Os dispositivos de 'curtir' e 'compartilhar' permitem que cada usuário consinta, aprove, repasse, publique postagens." (ROSA; SANTOS, 2013, p. 176, grifos dos autores), constituindo-se em maneiras de expressar aquilo que se sente e se pensa.

A partir dessa investigação, os referidos autores inferiram que mundo virtual e real se 
convergem e não, necessariamente, se opõem. Ainda que a não presença física possa permitir mais facilmente simulações ou dissimulações de sentimentos.

Nesse sentido, é interessante destacar alguns aspectos de estudos publicados no livro Sexo, Afeto e Era Tecnológica: Um Estudo de Chats na Internet, organizado por Porto (1999). Ainda no início das redes sociais virtuais, os pesquisadores identificaram que os discursos nos chats se constituíam numa "mera repetição do que se diz na vida real" (HAJE; ATTUCH, 1999, p. 94). Segundo as autoras, revelaram-se impregnados de velhos estereótipos (neste caso, em relação à sexualidade), excessivamente influenciados pela linguagem e jargões presentes nos meios de comunicação de massa, apesar da inovadora ferramenta e da aparente liberdade facilitada pelo anonimato dos seus usuários.

No contexto atual, e em relação ao agronegócio, é possível supor que tal influência (do discurso da mídia) também se revele presente na linguagem e no conteúdo dos comentários produzidos via Facebook, assim como ocorre na vida real em relação às RS, de uma maneira geral, segundo Jodelet (1989). E contrastando com o que foi dito sobre simulações ou dissimulações no uso das redes sociais, nesta rede, é perceptível que, muitas vezes, o anonimato (perfis com nome fictícios ou que pouco revelam sobre seus usuários) parece ter o intuito oposto, ou seja, poder desvelar o que realmente se pensa, sem a crítica ou julgamento por parte dos outros usuários, sejam conhecidos ou não.

No estudo por meio de chats, um dos pesquisadores ponderou que $\mathrm{o}$ anonimato os impediram de tratar as frases e conceitos dos usuários como realmente autênticos, por isso, acabaram se referindo a "[...] uma 'verdade da rede', dando crédito de veracidade a tudo o que nos foi dito em conversas particulares nos chats" (CUNHA, 1999, p. 101, grifo nosso). Da mesma maneira, nesta investigação, considera-se que há também uma "verdade da rede", na medida em que os comentários dos usuários expressam a inteligibilidade que estes têm do mundo, com suas crenças e formas de representar as coisas, no presente estudo: o agronegócio.

Esta inteligibilidade diz respeito às RS que, segundo Jodelet (1989), referem-se a um conhecimento prático que permite dar sentido aos contextos social, material e ideológico em que se vive. A autora reforça que elas condensam um conjunto de significados, a partir dos marcos de referências dos sujeitos, permitindo interpretar e dar sentido, inclusive, ao inesperado. Elas trazem incorporadas uma moral social e, muitas vezes, chegam prontas aos sujeitos carregadas de conteúdo ideológico (JODELET, 1989).

Segundo Moscovici (1979, p. 40) os sujeitos se apropriam do conhecimento transformando um conhecimento indireto em direto, tornando "[...] familiar lo insólito e insólito lo familiar". Nesta operação, o conhecimento é transmutado, sofre associações e dissociações, ajustando-se ao universo de valores, interesses, experiências, hábitos, costumes e conhecimentos anteriores dos sujeitos (MOSCOVICI, 1979).

Como característico desta forma de pensar, Moscovici (1979) destaca o uso de clichês, juízos e expressões conhecidas e redundantes (iteração) e a prevalência de proposições pregnantes e conclusivas que são conhecidas antes das premissas. Ele aponta que dois processos cognitivos atuam na formação da representação: a ancoragem e a objetivação. No primeiro, o conhecimento novo é captado e mesclado ao marco de referência dos sujeitos (ao conhecido); no segundo, ele toma forma mais concreta, cristalizada, condensando significados variados. Importante destacar, a implicação dos sujeitos naquilo que conhecem, denominada pelo autor como focalização, 
ela sinaliza para o fato de que, no esforço para dar inteligibilidade a um objeto social, os sujeitos focam naquilo que lhes é de interesse enquanto indivíduo ou grupo: "El esfuerzo esencial del sujeto no es para comprender esta teoria [teoria psicanalítica, naquele caso] en el marco que le es proprio, sino para delimitarla, destacarla de las perspectivas que están de acuerdo con sus orientaciones profundas." (MOSCOVICI, 1979, p. 178).

Constituindo-se em uma das dimensões das $\mathrm{RS}$, as atitudes dizem respeito ao posicionamento favorável ou desfavorável dos sujeitos em relação ao objeto social da representação (MORA, 2002). Dimensão mais frequente e visível, ela é, segundo Moscivici (1979), também responsável pela representação na medida em que a orienta. Não obstante, ele aponta outras dimensões como a informação - que diz respeito ao quanto o conhecimento do grupo, em relação a um determinado objeto social, está organizado - e o campo da representação - o conteúdo concreto, a imagem, o modelo social constituído pelo grupo para representar o objeto.

Considerando as atitudes, no Facebook de uma maneira geral, elas são expressas por meio de curtidas, de reações diversas (com o uso de emojis ou emoticons), de compartilhamentos e de comentários. Trata-se, assim, do formato específico da comunicação estabelecida neste espaço virtual e que tende a reproduzir a informalidade da linguagem oral, ainda que no discurso escrito (RIBEIRO; AYRES, 2014; RECUERO, 2008). Ao mesmo tempo, as interações e os conteúdos das postagens e informações veiculadas contribuem para formar, mudar ou fortalecer determinadas crenças, ideias, opiniões e atitudes. Verifica-se que aquele indivíduo, que há alguns anos parecia ser mero receptor ou telespectador, encontrase ainda mais empoderado, conforme apontado por Shirky (2011).
No que se refere à temática deste estudo - RS de agronegócios -, ressalta-se o estudo feito por Silva e Guimarães (2016) por meio da análise de matérias publicadas (entre 2014 e 2015) na Revista Veja. As autoras identificaram a prevalência de uma visão favorável do agronegócio, sendo este associado exclusivamente à produção agropecuária em escala. Segundo elas, na perspectiva favorável, o setor é representado como uma espécie de "herói" que luta contra forças que lhes fazem oposição: as crises econômicas, o MST (Movimento dos Sem-Terra) e a FUNAI (Fundação Nacional do Índio). Nesse sentido, é fortemente associado à produção, ao crescimento e à sustentação da economia no Brasil. No que tange à perspectiva desfavorável, menos presente nas reportagens, o agronegócio foi representado como uma espécie de "vilão", sendo a ele associados o desmatamento e as ações depredatórias na natureza, de uma maneira geral. As autoras acrescentam que as matérias reforçam a separação ideológica entre a produção denominada patronal da produção familiar.

$$
\text { Cappellesso e Guimarães (2016) e }
$$
Cappellesso, Guimarães e Carvalho (2019) estudaram as RS de estudantes de cursos de gestão de agronegócios. Eles identificaram que boa parte dos discentes também tendem a associá-lo à grande produção agropecuária e, ao mesmo tempo, desassociá-lo de elementos percebidos como socialmente negativos como desmatamento e más condições de trabalho. Segundos os autores, a RS de agronegócios dos estudantes de períodos iniciais do curso, principalmente, está alinhada àquela reproduzida pela grande mídia, onde é mais comumente vinculado à produção em escala e à alta tecnologia. Eles observaram que à medida que os estudantes evoluíam nos cursos, suas representações sobre o agronegócio ampliavam-se, novas associações eram a ele incorporadas. 
Os autores supracitados destacam a distância destas RS do conceito acadêmico de agronegócio que, compreendido numa perspectiva sistêmica, abarca outros elos produtivos para além da produção agropecuária. Academicamente, agronegócio tem sido compreendido em termos de Sistemas Agroindustriais, implicando numa rede de interações que envolvem a produção de diferentes commodities agropecuárias (ZYLBERSZTAJN; NEVES, 2000).

O estudo encomendado pela Associação Brasileira de Agronegócio (2013) e conduzido pela Escola Superior de Propaganda e Marketing relacionase aos anteriores na medida em que levantou a percepção dos brasileiros sobre o agronegócio. O estudo foi realizado com 616 pessoas. A investigação revelou que: a) 40,4\% dos entrevistados nunca havia ouvido falar em agronegócio; b) dos 59,6\% que haviam ouvido falar, a maioria, o relacionava a atividades "dentro da porteira"; c) boa parte dos entrevistados associavam positivamente o agronegócio à geração de emprego, não obstante, uma boa parte o associava ao desmatamento e ao consumo intensivo de água; d) $81,3 \%$ o consideraram muito importante para a economia.

A abundância ou ausência de informações, os assuntos polêmicos e de interesse comum, as descobertas da ciência que desconfortam e causam estranhamento, a necessidade humana de fazer parte do mundo comunicacional e relacional fazem aflorar as RS (MOSCOVICI,1979). Em se tratando especificamente do agronegócio, essas características se fazem presentes e bastante pertinentes. Não há dúvida de que o espaço virtual e abundante de informações das redes sociais se constitui em um espaço para expressão das RS, em relação aos diferentes objetos sociais. Saberes, afetos, memória individual coletiva são utilizados para interpretar o mundo e comunicá-lo aos outros (SANTOS; ICHIKAWA, 2018) também neste espaço virtual.

\section{MÉTODO}

Para investigar as RS sobre o Agronegócio a partir de opiniões expressas no Facebook foi realizada uma pesquisa do tipo como exploratória (GERHARDT; SILVEIRA, 2009). Inicialmente, identificou-se um veículo de comunicação (Jornal) com circulação expressiva nesta rede social. Considerando o número de curtidas na página, inicialmente, identificou-se a Folha de S. Paulo que registrava 5.798.768 curtidas. Contudo, o jornal parou de atualizar suas matérias no Facebook desde janeiro de 2018. Sendo assim, optou-se pelo O Globo que apareceu em segundo lugar com 5.715.110 curtidas na página. Segundo Sacchitiello (2019), O Globo é o segundo veículo com maior circulação digital do país e vem apresentando, nos últimos anos, as maiores taxas de crescimento.

Definido o veículo, a tarefa foi identificar publicações que abordavam a temática agronegócio para análise. Os passos e critérios utilizados são explicitados a seguir:

a) Procedeu-se na busca de reportagens por meio do sistema de pesquisa disponível no Facebook, utilizando-se o descritor "agronegócios". Como o resultado não foi satisfatório (apenas uma publicação), utilizou-se o mesmo termo no singular;

b) foram retornadas 16 reportagens. Destas, foram excluídas aquelas que não continham o termo no texto superior da publicação nem no título da matéria $(n=3)$ e outra que continha o termo, mas não tratava especificamente do tema $(n=1)$;

c) verificou-se, numa leitura inicial, que aquelas que continham o termo, mas que foram publicadas entre 2018 e 2019 ( $n=7$ ), estavam continham, quase que exclusivamente, comentários políticos. Restando, assim, cinco publicações; 
d) destas cinco, optou-se pela publicação mais recente (out./2017): "Emissão de gases do efeito estufa no Brasil cresce 9\% em 2016" (O GLOBO, 2017);

e) definida a reportagem, foi feita a organização do material para posteriores análises.

Nos resultados apresentados a seguir, privilegiou-se inicialmente uma análise descritiva do material (comentários de 93 usuários do Facebook ao post/matéria) e a análise de conteúdo, propriamente dita. Análises textuais também foram realizadas por meio do software Iramuteq. Conforme apontado por Salviati (2017), trata-se de um software livre, utilizado nos estudos das Ciências Humanas e Sociais, que realiza análises estatísticas de textos, incorporando, além da Classificação Hierárquica Descendente, outras análises lexicais que auxiliam no exame e interpretação de textos diversos, sendo uma ferramenta importante para a investigação das RS.

\section{RESULTADOS E DISCUSSÃO}

Conforme destacado, o título da matéria, e que aparece abaixo de uma imagem de uma área desmatada na postagem, é: "Emissão de gases do efeito estufa no Brasil cresce 9\% em 2016". Acima da imagem está a chamada para a matéria da jornalista Luiza Souto: "Agronegócio é apontado como o principal responsável pela emissão de poluentes". A reportagem faz referência ao estudo divulgado pelo Observatório do Clima que apontou para o crescimento da emissão de gases do efeito estufa no Brasil, colocando o país em sétima posição no ranking dos países mais poluidores. Os dados destacados revelam que o Brasil foi a única grande economia do mundo a crescer, em termos dessa emissão, sem ter como contrapartida o crescimento da riqueza. Como a principal causa para este aumento na emissão de gases, o Observatório destaca o agronegócio, sendo este responsável por $74 \%$ do total da emissão de gases. Ligados ao agronegócio estão o desmatamento da
Amazônia e a emissão de gases como $\mathrm{CO} 2$ (gás carbônico) e N2O (óxido nitroso) por bovinos. A figura 1 apresenta o print do post relativo à reportagem e as reações dos seguidores.

Figura 1. Matéria do Jornal analisada e reações dos seguidores.

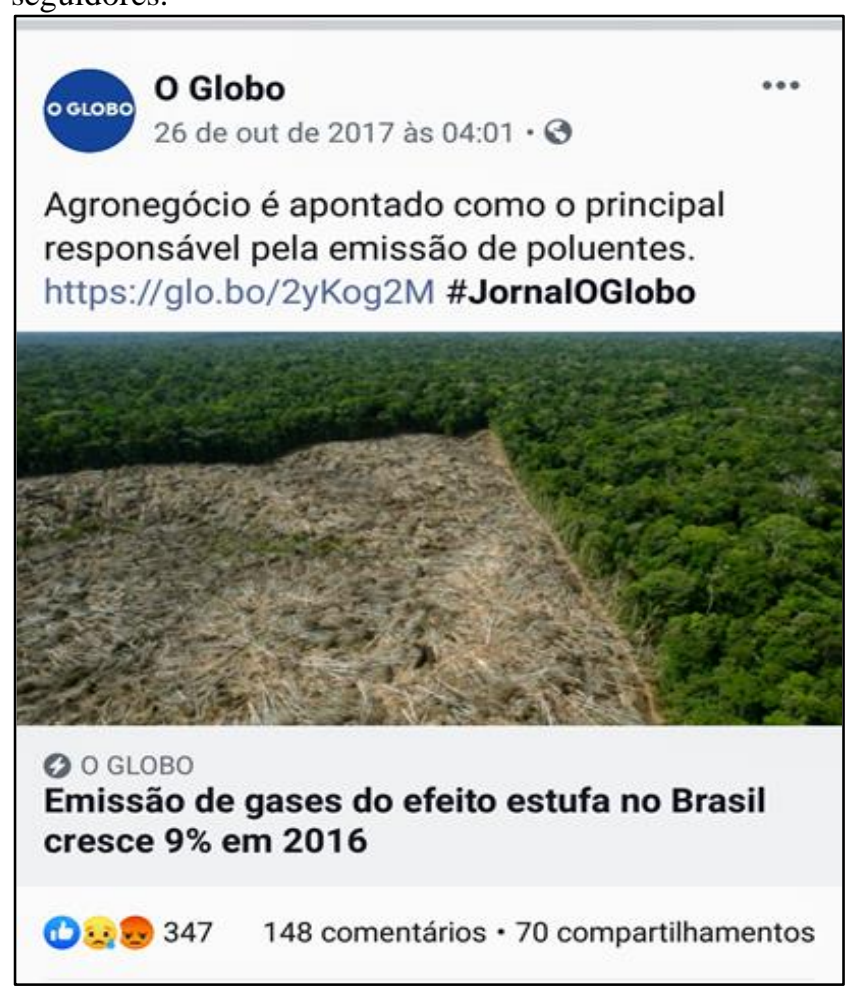

Fonte: O Globo (2017).

O post da matéria veiculada pelo Jornal gerou 347 reações dos seguidores, 148 comentários e 70 compartilhamentos (Cf. tabela 2). As reações revelam atitudes e sentimentos e vários diante do conteúdo do post/matéria, sendo identificados pelos mesmos símbolos (emojis) disponibilizados pela rede social.

Tabela 1. Reações dos seguidores do Jornal ao post matéria.

\begin{tabular}{|c|c|c|c|c|c|c|}
\hline 192 & 1 & 71 & 52 & 16 & 15 & 347 \\
\hline $55,3 \%$ & $0,3 \%$ & $20,5 \%$ & $15,0 \%$ & $4,6 \%$ & $4,3 \%$ & $100,0 \%$ \\
\hline
\end{tabular}

Fonte: Elaborada pelos autores.

Não obstante, as reações visualmente destacadas não permitiram identificar ao certo a atitude dos sujeitos em relação à mesma. $\mathrm{O}$ riso, por 
exemplo, poderia representar reação de sarcasmo daqueles que não acreditam no conteúdo da matéria divulgada - "Isso já está provado que é fake." como, também, daqueles que concordam com seu conteúdo, mas reagem de forma irônica junto ao veículo de comunicação - "Mas o Agro não é bom? Não é pop?". Sendo assim, buscou-se analisar mais detalhadamente as atitudes dos usuários/seguidores por meio dos comentários.

Conforme apontado, a matéria gerou 148 comentários, contudo só foi possível a visualização de 108 comentários, ou seja, $73,5 \%$ do total de comentários feitos por 93 seguidores, constituindo, estes no corpus para análise de conteúdo. Destes 108 comentários, uma minoria se constituiu em réplica ou tréplica a alguma contestação feita. Assim, numa tentativa inicial de organização deste corpus, buscouse identificar a atitude em relação ao agronegócio. Conforme apontado por Moscovici (1979), esta constitui-se na mais visível e frequente dimensão das RS. Os comentários foram categorizados como: favorável/positivo, desfavorável/negativo e neutro. Nesta última, foram incluídos os comentários daqueles em que não foi possível captar claramente a atitude diante do objeto social aqui investigado. Por vezes sarcásticos, comentários como por exemplo: “culpa do PT", "Pirou?" ou "Mintiiiiiiirinha...", não deixavam perceptíveis o real posicionamento.

O posicionamento favorável ao agronegócio foi identificado em $38,7 \% \quad(n=36) \quad \operatorname{dos}$ usuários/seguidores, desfavorável em 32,3\% (n=30) e o neutro ou não captado representou 29,0\% (n=27) dos usuários/seguidores. Na seção seguinte, estes posicionamentos são mais bem descritos.

\subsection{O ponto de vista dos que se posicionaram} favoráveis ao agronegócio

Considerando aqueles que se posicionaram de maneira favorável e quase numa espécie de defesa do agronegócio $(n=36)$, a maioria expressou um descrédito em relação ao conteúdo da reportagem e/ou em relação ao veículo de comunicação. Não obstante, poucos defenderam sua posição com argumentos positivos e consistentes em relação ao agronegócio. A polarização política no país nos últimos anos aparece presente em boa parte dos argumentos dos usuários.

Os seguintes temas orientaram a categorização temática (BARDIN, 1977) realizada: a) Negação foram incluídos os argumentos que negam o efeito estufa e o aquecimento global; b) Desqualificação do veículo de comunicação - incluídos aqueles que desqualificam o meio de comunicação com adjetivos pejorativos e/ou acusando-o, por exemplo, de comunista ou de divulgar as chamadas fake news; c) Benefícios do agronegócio - incluídos argumentos que apontam algo positivo em relação ao agronegócio; d) Desqualificação da esquerda - argumentos que alinham a "agenda ambientalista" a um discurso de esquerda; e) Desqualificação dos cientistas - criticam e/ou desqualificam os cientistas; f) Outros argumentos que não se enquadraram nas categorias anteriores; g) Xingar - argumentos em que prevaleceu apenas essa forma apelativa de agressão verbal.

Para a categorização foram acatados 41 argumentos dos 36 usuários já citados. O quadro 1 apresenta o conteúdo dos comentários, considerando a categorização feita.

\footnotetext{
${ }^{1}$ Verbalizações literais retiradas dos usuários/seguidores que comentaram o post/matéria.
} 
Quadro 1. Categorização dos argumentos daqueles que se posicionam favoráveis ao agronegócio.

\begin{tabular}{|c|c|c|}
\hline \multicolumn{3}{|c|}{ Argumentos favoráveis ao Agronegócio } \\
\hline Categorias & Exemplos de Argumentos & Freq. \\
\hline \multirow{4}{*}{ Negação } & "O efeito estufa não existe. É uma falácia para os poderosos ganharem dinheiro" & \multirow{4}{*}{18} \\
\hline & $\begin{array}{l}\text { "ninguém me convence que vacas são a maior fonte de CO2 do mundo e que isso prejudica o } \\
\text { meio ambiente... sério que acham que animais peidando destróem o planeta?" }\end{array}$ & \\
\hline & $\begin{array}{l}\text { "fato é que segundo a própria ciência, pelo menos segundo boa parte dos cientistas, essa coisa } \\
\text { de emissão de gases no efeito estufa, é conversa pra boi peidar! Isso não existe!!! Com a } \\
\text { palavra: Luiz Carlos Molion!" }\end{array}$ & \\
\hline & "Coisa de gringo para interferir no agro negócio brasileiro." & \\
\hline \multirow{3}{*}{$\begin{array}{l}\text { Desqualificação } \\
\text { do veículo de } \\
\text { comunicação }\end{array}$} & “ 'O Brasil é Agro’. Oglobo é Gramsci.” & \multirow{3}{*}{11} \\
\hline & $\begin{array}{l}\text { "Globosta e a solução do Brasil, mas a pecuária e a produção de grãos e o problema, esse e o } \\
\text { nosso Brasil de hoje." }\end{array}$ & \\
\hline & "Ixo eh mais uma mentira da rede esgoto juntamente cm o governo pra enganar o gado. [...]" & \\
\hline \multirow{3}{*}{ Benefícios } & "O Agronegócio foi responsável pelo pais não quebrar nestes ultimos 5 anos." & \multirow{3}{*}{5} \\
\hline & "O Agronegócio é o principal e único responsável por termos o que comer todos os dias [...]" & \\
\hline & "Alguem tem que colocar comida no prato do brasileiro" & \\
\hline \multirow{2}{*}{$\begin{array}{l}\text { Desqualificação } \\
\text { da esquerda }\end{array}$} & $\begin{array}{l}\text { "a agenda ambiental serve apenas pra acabar com a oferta de produtos, com a produção } \\
\text { industrial, consequentemente elevação de preços e redução de empregos É mais uma arma } \\
\text { contra o livre comercio, mais um mecanismo dessa esquerda nojenta de propagar o mau." }\end{array}$ & \multirow[t]{2}{*}{2} \\
\hline & $\begin{array}{l}\text { "Isso, comunistada de merda, vamos acabar com o Agronegócio, aí poderemos todos comer } \\
\text { merda e inseto com quer a ONU! MORTE A PESTE VERMELHA!" }\end{array}$ & \\
\hline \multirow{2}{*}{$\begin{array}{l}\text { Desqualificação } \\
\text { dos cientistas }\end{array}$} & "esses pseudo-cientistas vendidos a uma agenda tão de sacanagem." & \multirow[b]{2}{*}{2} \\
\hline & $\begin{array}{l}\text { "Quem tá medindo??? onde está o laudo cientifico?? Quais cientistas decentes comprovam } \\
\text { com fatos essa tese?" }\end{array}$ & \\
\hline \multirow[b]{2}{*}{ Outro } & "Cresce mais que tá pouco!"” & \multirow[b]{2}{*}{2} \\
\hline & $\begin{array}{l}\text { Gildrsn Vasconcelos ciência?? Vc sequer cita o nome das principais revistas científicas ou um } \\
\text { artigo científico validado pela comunidade internacional e vem falar de ciência? Link do } \\
\text { Estadão é ciência? Kkkkk }\end{array}$ & \\
\hline Xingar & $\begin{array}{l}\text { "Larga de ser besta; cambada de JUMENTOS! Vocês vão comer merda no café da manhã, } \\
\text { almoço e jantar! Uma geração de idiotas!" }\end{array}$ & 1 \\
\hline
\end{tabular}

Fonte: Elaborado pelos autores. Redação ipisis litteris, tal qual publicada nos comentários.

É pertinente destacar que a prevalência do posicionamento favorável ao agronegócio foi também identificada por Silva e Guimarães (2016) no veículo de comunicação por elas analisado, bem como no levantamento realizado pela ABAG (2013). Interessante recordar que, muitas vezes, as representações chegam prontas e carregadas de conteúdo ideológico (JODELET, 1989). Nos comentários expressos pelos usuários/seguidores essa premissa se faz pertinente, principalmente, no teor das refutações ao post/matéria e aos comentários dos "opositores". A adjetivação utilizada, não obstante, serve mais para criticar e desqualificar os que pensam diferente e menos para qualificar o agronegócio.
Nestes comentários, verifica-se a utilização de uma linguagem não só informal, como destacado por Ribeiro e Ayres (2014) e Recuero (2008), mas também bastante agressiva e/ou desqualificadora para impor o ponto de vista, sendo emblemáticos os comentários: "Isso, comunistada de merda, vamos acabar com o Agronegócio, aí poderemos todos comer merda e inseto com quer a ONU!..." e "Larga de ser besta; cambada de JUMENTOS! Vocês vão comer merda no café da manhã, almoço e jantar! Uma geração de idiotas!".

Tendo em conta as características das RS, tanto em relação ao agronegócio quanto ao efeito estufa, pode referir-se a elas como pregnantes (de forte impacto e possuidora de uma estabilidade), 
redundantes, reprodutoras de clichês, conclusivas e carregadas de valores, características comuns às representações (MOSCOVICI, 1979). Os comentários, nesse sentido, não se abrem para o diálogo ou para o contraditório, mas encerram em si mesmos: "Não existe a menor evidência da existência de 'efeito estufa'. Próximo".

Considerando ainda a dimensão informação das RS (MOSCOVICI, 1979) é possível inferi-la como precária, apesar da abundância sobre o tema na atualidade. Tal inferência se confirma na já ressaltada ausência de argumentos consistentes.

Assim como identificado por Silva e Guimarães (2016), o agronegócio, na perspectiva destes usuários/seguidores, parece "lutar" contra inimigos e forças, às vezes quase ocultas, como expressado pelo usuário: "Ixo eh mais uma mentira da rede_esgoto juntamente cm o governo pra enganar o gado. A crise nao existe ixo tudo eh uma simulacao pra diminuir a populacao humana no brasil e no mundo [...]. Nesse sentido, é possível destacar como “inimigos" e forças opositoras ao agronegócio brasileiro: a esquerda comunista, os pseudocientistas, os gringos, o governo, a agenda ambiental, os poderosos e a mídia. Essa dissociação refere-se à dimensão relativa ao campo da representação (MOSCOVICI, 1979), revelando a lógica dos argumentos e a busca de sentidos pelos sujeitos.

Em que pese a pouca qualificação ao agronegócio, propriamente dito, aqueles que assim o fizeram consideraram sua importância econômica, como também identificado por Silva e Guimarães (2016) e a ABAG (2013), bem como seu papel como supridor de alimentos.

\subsection{O ponto de vista dos que se posicionaram} desfavoráveis ao Agronegócio

Considerando aqueles que em seus comentários se posicionaram mais desfavoravelmente em relação ao agronegócio $(n=30)$, os argumentos foram, em sua maioria, uma crítica velada (em forma de sarcasmo) ou aberta ao agronegócio e ao veículo de comunicação Jornal O Globo ou à Rede Globo. Constata-se que ambos os grupos acusam a emissora de defender um dos lados. No presente grupo, o próprio jargão de uma das publicidades da emissora foi utilizado para expressar essa atitude: “AGRO é pop! AGRO é tudo né Globo???”, “Agro polui - Agro é pop - Agro mata!". Vê-se, conforme expressão de Castells (2005), “a imperiosa" mediação de um canal institucionalizado sendo questionada pelos usuários do Facebook.

Como na seção anterior, buscou-se categorizar os argumentos deste grupo (Cf. quadro 2). De uma maneira geral, a grande maioria se posicionou de forma crítica em relação ao agronegócio, entretanto, no conjunto de argumentos categorizados como "Criticam o agronegócio elou os agropecuaristas" foram incluídos aqueles que fizeram menção mais abertamente a estes, como também aqueles que, sarcasticamente, utilizaram o próprio tema da publicidade já mencionada, criticando, de certa forma e ao mesmo tempo a emissora. Na categoria "Criticam o veículo de comunicação", foram incluídos somente aqueles que mais abertamente o criticaram ou questionaram o fato de fazerem publicidade que consideram ser a favor do agronegócio.

Como destacado em relação ao outro grupo, proposições conclusivas também aparecem ( "AGRO é desmatamento. AGRO é aquecimento global. AGRO é selvageria capitalista..."), bem como os clichês (“Derruba árvore pra criar gado!!!"). Não obstante, argumentos um pouco mais elaborados tentaram dar conta do problema ("A política de fiscalização para contenção de desmatamento e de queimadas é errônea $e$ insuficiente. $O$ índice de eficiência apontado no último levantamento efetuado é ridículo. Aponta cerca de $5 \%$ quando deveria ser de no mínimo 50\%.). 
Quadro 2. Categorização dos argumentos daqueles que se posicionam desfavoráveis ao agronegócio.

\begin{tabular}{|c|c|c|}
\hline \multicolumn{3}{|c|}{ Argumentos favoráveis ao Agronegócio } \\
\hline Categorias & Exemplo de Argumentos & Freq. \\
\hline \multirow{4}{*}{$\begin{array}{l}\text { Criticam o } \\
\text { Agronegócio e/ou } \\
\text { agropecuaristas }\end{array}$} & "AGRO é desmatamento. AGRO é aquecimento global. AGRO é selvageria capitalista." & \multirow{4}{*}{11} \\
\hline & "Derruba árvore pra criar gado !!!" & \\
\hline & $\begin{array}{l}\text { "Agro negócio/ criação de gado! Os inimigos do meio ambiente!! Não vem comeste papo } \\
\text { que a agricultura e criação de gado é para alimentar o povo!! Aqui no país ficam para os } \\
\text { brasileiro apenas uma pequena porcentagem do que é produzido, a maioria e só o que é de } \\
\text { boa qualidade são exportados!! Nós pagamos várias vezes por isso, porque os agricultores e } \\
\text { criadores de gado tipo exportação, desmatam, queimam, destroem florestas inteiras e ainda } \\
\text { recebem subsídios do governo [...] }\end{array}$ & \\
\hline & $\begin{array}{l}\text { "Em uma unica unidade de um frigorifico, o Maggi, mais de } 7000 \text { gados sao abatidos por } \\
\text { dia. Faz ideia de quantos estao vivos, sendo criados. Povo burro demais. Acha que } \\
\text { antigamente era como hoje. Hoje é o apocalipse mermao!" }\end{array}$ & \\
\hline \multirow{3}{*}{$\begin{array}{l}\text { Criticam o } \\
\text { veículo de } \\
\text { comunicação }\end{array}$} & “AGRO é pop! AGRO é tudo né Globo???” & \multirow{3}{*}{6} \\
\hline & $\begin{array}{l}\text { "Agro é pop...agro é bom...passou na Globolixo não.presta.Está aí a prova.Anunciou na } \\
\text { Globo ,não compre.Simples” }\end{array}$ & \\
\hline & "Mas o Agro não é bom? Não é pop?" & \\
\hline \multirow{2}{*}{$\begin{array}{l}\text { Criticam e } \\
\text { responsabilizam } \\
\text { os políticos }\end{array}$} & $\begin{array}{l}\text { "Tem Que Levar Todos Os Políticos Ruralistas Para Instalar Seus Escritórios Ali. E Respirar } \\
\text { Apenas O "Ar" Que Ali É Produzido." }\end{array}$ & \multirow{2}{*}{4} \\
\hline & $\begin{array}{l}\text { "O pior é que os responsáveis muitos estão no congresso e os demais aliados. Estão } \\
\text { acabando com nossas matas em nome da ambição [...] }\end{array}$ & \\
\hline \multirow[b]{2}{*}{ Outro } & $\begin{array}{l}\text { "250 milhões de cabeças de gado em um processo de digestão que libera grande quantidade } \\
\text { de metano, cujo potencial para causar o efeito estufa é } 25 \text { vezes maior que o CO2" }\end{array}$ & \multirow[b]{2}{*}{4} \\
\hline & $\begin{array}{l}\text { "O maior parte do gás emitido sai do arroto (durante o processo digestivo) Animais sempre } \\
\text { peidaram como disseram.....mas qdo começamos a criar bovinos em larga escala como } \\
\text { estamos.fazendo no Brasil.... além do gás...o desmatamento predatório que estão fazendo é } \\
\text { bizarro" }\end{array}$ & \\
\hline \multirow[t]{2}{*}{$\begin{array}{l}\text { Culpabilizam a } \\
\text { ação do homem }\end{array}$} & $\begin{array}{l}\text { "o efeito estufa acontece naturalmente no nosso planeta, mas a ação antrópica agrava esse } \\
\text { efeito, aumentando significativamente a temperatura do planeta. Desequílibrio climático } \\
\text { afeta ecossistemas inteiros e suas dinâmicas. }\end{array}$ & \multirow[t]{2}{*}{2} \\
\hline & "O homem, esta acabando com mundo.... & \\
\hline $\begin{array}{l}\text { Lamentam o } \\
\text { Brasil }\end{array}$ & "BRASIL so se destaca em coisas negativas......." & 2 \\
\hline $\begin{array}{l}\text { Criticam } \\
\text { políticas públicas } \\
\text { e órgãos } \\
\text { governamentais }\end{array}$ & $\begin{array}{l}\text { "A política de fiscalização para contenção de desmatamento e de queimadas é errônea e } \\
\text { insuficiente. O índice de eficiência apontado no último levantamento efetuado é ridículo. } \\
\text { Aponta cerca de } 5 \% \text { quando deveria ser de no mínimo } 50 \% \text {. }\end{array}$ & 1 \\
\hline
\end{tabular}

Fonte: Elaborado pelos autores. Manteve-se a redação ipisis litteris, tal qual publicada nos comentários.

Como identificado por Cappellesso e Guimarães (2016), Silva e Guimarães (2016) e Cappellesso, Guimarães e Carvalho (2019), os argumentos de ambos os grupos permitem inferir ser o agronegócio representado pela produção agropecuária em escala. A produção familiar parece ser excluída do entendimento do que se constitui o agronegócio, bem como os demais elos das cadeias produtivas.

As análises textuais seguintes complementam estas análises lançando luz sobre as representações de ambos os grupos.

\subsection{Análises textuais por meio do Iramuteq}

Conforme descrito, para análise mais detalhada das RS, utilizou-se também o software livre Iramuteq. Para tal, considerou-se o conjunto de comentários, incluindo réplicas e tréplicas e excluindo colocação de links para outros sítios. Para isso, correções ortográficas ao texto foram necessárias, mantendo-se fiel ao seu sentido. O corpus geral foi constituído por 104 textos, separados por 130 segmentos de texto (ST), com aproveitamento de 97, 
ou seja, de 74,62\% ${ }^{2}$. Emergiram 2162 ocorrências (palavras, formas ou vocábulos), sendo 522 palavras distintas, com uma única ocorrência (hapax). O conteúdo analisado foi classificado em seis classes de palavras: a primeira com $13,4 \%$, a segunda com $15,5 \%$, a terceira com $22,7 \%$, a quarta com $15,5 \%$, a quinta com $17,5 \%$ e a sexta com $17,5 \%$ (Cf. figura 2 ).

Figura 2. Dendograma da classificação hierárquica descendente (CHD).

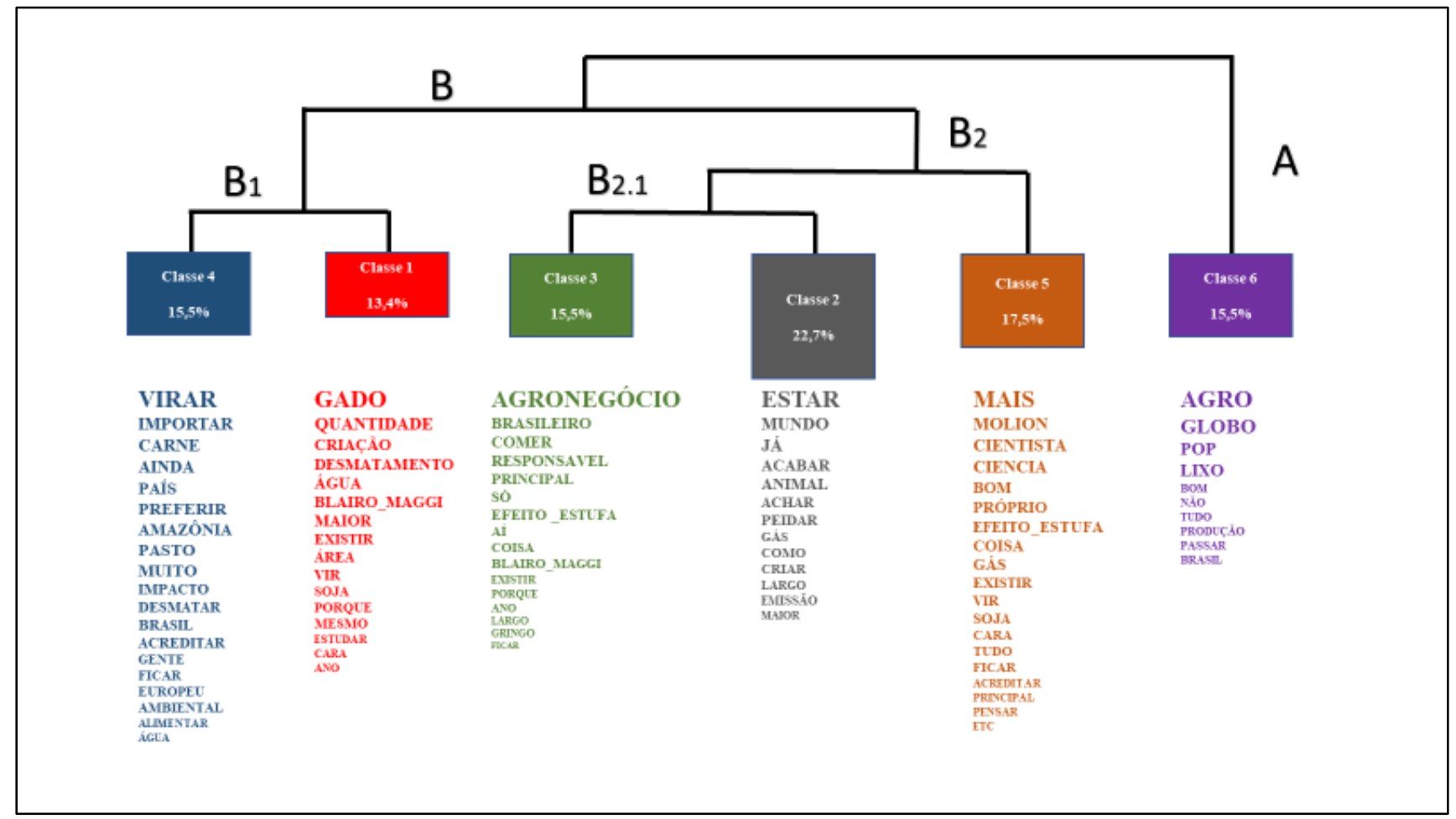

Fonte: Extraído a partir das análises textuais do software Iramuteq.

De acordo com Veloz, Nascimento-Schulze e Camargo (1999 apud CAMARGO; JUSTO, 2013, p. 6), estas classes podem indicar "teorias ou conhecimentos do senso comum ou campos de imagens sobre um dado objeto, ou ainda apenas aspectos de uma mesma representação". Para maior compreensão, foi feita uma Classificação Hierárquica Descendente (CHD), nesta, "os segmentos de textos e seus vocabulários são correlacionados, formando um esquema hierárquico de classes de vocabulário" (LINS, 201-, p. 23). Verificou-se que as classes se encontram subdivididas em várias ramificações do corpus total (duas ramificações centrais - A e B - e esta última, em mais três ramificações - $B_{1}, B_{2}$ e $\left.B_{2.1}\right)$, conforme demonstrado na figura 2.

O subcorpus A recebeu a denominação “ $O$ pop não poupa ninguém" e é composto pela classe 6 . Nesta, destaca-se a desconfiança em relação à emissora e ao conteúdo da campanha publicitária " $O$ agro é tech, o agro é pop, o agro é tudo".

O subcorpus B foi denominado "Amigo ou Inimigo?" e encontra-se subdividido em duas categorias $\mathrm{B}_{1}$ e $\mathrm{B}_{2}$, sendo que, esta última, subdividese em mais uma categoria $\left(\mathbf{B}_{2.1)}\right.$. Integram ao subcorpo B as classes 1, 2, 3, 4 e 5. É perceptível neste conjunto de segmentos textuais o conflito entre os benefícios que o agronegócio traz às pessoas e ao país e os

\footnotetext{
${ }^{2}$ Segundo Lins (201-) para ser representativo, o valor mínimo a ser considerado deve ser de $70 \%$.
} 
malefícios, quando se considera o meio ambiente. Nas classes 1 e $4\left(B_{1}\right)$ encontram-se os argumentos que revelam a percepção de um agronegócio Inimigo: que exporta, mas desmata. Na classe $5\left(\mathrm{~B}_{2}\right)$ a ciência e os cientistas são questionados e colocados em xeque. Já nas classes 2 e 3 o conflito entre o agronegócio "Amigo ou Inimigo" permanece, bem como a sua defesa ou incriminação.

$\mathrm{Na}$ seção seguinte, buscou-se aprofundar ainda mais no entendimento das representações, por meio da análise detalhada de cada uma destas classes.

\subsubsection{O pop não poupa ninguém}

A classe 6 abarca 15, 5\% ( $f=15$ ST $)$ do corpus total analisado (aproveitamento de130 ST/74,62\%). Sobressaem nesta classe palavras como: Agro $\left(X^{2}=\right.$ 60,95); Globo $\left(X^{2}=60,95\right) ;$ Pop $\left(X^{2}=34,96\right)$ e Lixo $\left(X^{2}\right.$ $=16,8){ }^{3}$

Como destacado por Shirky (2011), o usuário das redes sociais encontra-se empoderado, não recebendo passivamente uma informação. Nesse sentido, na análise realizada verificou-se o questionamento de parte dos usuários ao conteúdo das mensagens veiculadas pela emissora e que tentam formar uma imagem positiva em relação ao agronegócio, mais especificamente, à campanha " $O$ agro é tech, o agro é pop, o agro é tudo". Esta, por sua vez, bastante conhecida pela população.

Corroborando com o que foi apontado (quadros 1 e 2), ao mesmo tempo em que a emissora é atacada por valorizar o agronegócio, nesta classe, também encontram-se segmentos de textos relativos aos comentários de usuários que a atacam por divulgar matéria que consideram ser contrária ao agronegócio, sendo expressões como Globosta e Globolixo utilizadas para desqualificar o veículo e a matéria. Ninguém é "poupado": O agro pop não poupa o meio

\footnotetext{
${ }^{3}$ Em todas as análises apresentadas, conforme recomendado por Lins [s.d], foram consideradas aquelas com $x^{2}>3,80(p<0,05)$, na
}

ambiente, a Globo pop não é poupada pelos usuários que também não poupam nos adjetivos.

Conforme destacado por Moscovici (1979), na tentativa de apropriação do conhecimento, no presente caso do discurso científico relativo à emissão de gases, os sujeitos utilizam vocábulos de origem diversas, bem como conceitos e condutas, sendo que um elemento que pertence a uma determinada categoria de atividade e do discurso social se transpõe para outro. Tal lógica, contraditória inclusive, é identificada na transposição dos conflitos políticos e do que estes carregam em termos de afetos. Assim, as representações do grupo favorável ao agronegócio caminham no sentido de associação da emissora com os posicionamentos de esquerda que, por sua vez, se associam aos dos ambientalistas e dos cientistas; enquanto que para o grupo oposto, ela aparece associada ao posicionamento de direita e com o "grande agronegócio destruidor do meio ambiente". A figura 3 trata-se de uma tentativa de delinear a lógica das representações e das associações feitas, aspectos ligados ao seu conteúdo concreto ou campo da representação (MOSCOVICI, 1979):

Figura 3. A lógica das representações e suas associações.

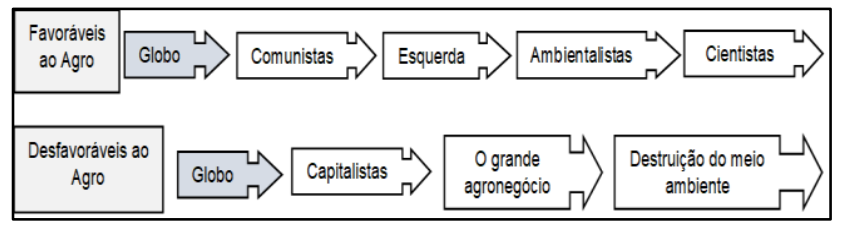

Fonte: Elaborada pelos autores.

As associações e dissociações seguem incorporando vários elementos para corroborar com as atitudes já adotadas pelos sujeitos, bem como dar inteligibilidade à realidade contraditória, abundante de informações e de conflitos ideológicos. As questões científicas postas pela reportagem não fazem menção aos aspectos partidários-ideológicos (direita/esquerda,

medida em que estas possuem significância em termos de associação da palavra com a classe. 
comunista/capitalista). Não obstante, tal associação parece ser rapidamente feita pelos dois grupos. A implicação dos sujeitos - focalização - na lógica delineada é clara, afetando o modo como cada um olha e interpreta o mesmo objeto social (MORA, 2002), direcionando as associações.

\subsubsection{Amigo ou inimigo?}

Como ressaltado, as demais classes pertencem a este subcorpus. Integrando a categoria $\mathrm{B}_{1}$ estão as classes 1 e 4 . A classe 1 compõe 13,4\% $(f=13$ ST) do corpus total analisado. Se destacam nesta classe palavras como: Gado $\left(X^{2}=64,1\right)$; Quantidade $\left(X^{2}=\right.$ 26,96); Criação $\left(X^{2}=13,64\right)$; Desmatamento $\left(X^{2}=\right.$ 12,44); Água $\left(X^{2}=12,44\right)$; Blairo Maggi $\left(X^{2}=7,57\right)$; Maior $\left(X^{2}=3,21\right)$.

Já a classe 4 abarca 15,5\% ( $f=15 \mathrm{ST})$ do corpus. As palavras que se destacaram foram: Virar $\left(X^{2}=28,82\right)$; Carne $\left(X^{2}=28,48\right)$; Ainda $\left(X^{2}=22,81\right)$; País $\left(X^{2}=22,02\right)$; Preferir $\left(X^{2}=16,92\right) ;$ Amazônia $\left(X^{2}\right.$ $=16,92) ;$ Pasto $\left(X^{2}=16,8\right) ;$ Muito $\left(X^{2}=14,76\right)$; Impacto $\left(X^{2}=11,31\right)$; Desmatar $\left(X^{2}=11,31\right)$; Brasil $\left(X^{2}=7,96\right) ;$ Acreditar, Gente, Ficar, Europeu e Ambiental $\left(X^{2}=6,21\right)$.

Prevalece na classe 1 a representação do agronegócio como uma espécie de "Inimigo" do meio ambiente, sendo personagens como Joesley Batista e Blairo Maggi (ruralistas e representantes do grande agronegócio) associados aos interesses deste "Inimigo". O comentário seguinte é representativo desta forma de pensar o agronegócio:

- Agro negócio/ criação de gado! Os inimigos do meio ambiente!! Não vem comeste papo que a agricultura e criação de gado é para alimentar o povo!! Aqui no país ficam para os brasileiro apenas uma pequena porcentagem do que é produzido, a maioria e só o que é de boa qualidade são exportados!! Nós pagamos várias vezes por isso, porque os agricultores e criadores de gado tipo exportação, desmatam, queimam, destroem florestas inteiras e ainda recebem subsídios do governo que vem de nossos impostos pagos, resumindo: Ficam ricos desmatando o país! Ganância pura!! Isso não é para nos alimentar!!

Tal argumento permite compreender a associação entre as classes 1 e 4 . Nesta última, os segmentos de textos analisados incorporam a ideia de um país sendo explorado pelos demais. Os países estrangeiros preservam o seu meio ambiente, enquanto o Brasil abre pasto na floresta, a desmata para alimentá-los:

- Pois é. A Amazônia virando pasto para alimentar gringo. :-

- [...] a verdade é que o desmatamento está acabando com a nossa área verde. Isso pra virar pasto. Muitos países europeus preferem importar carne do que criar bois pois sabem dos impactos ambientais [...].

- Justamente W. O. muitos países europeus preferem importar do que arcar com todos os impactos ambientais. Ao contrário do Brasil que tá deixando a Amazônia virar pasto.

Para grande parte dos usuários/seguidores a redução da importância da terra como fator de produção, conforme destacado por Buainain et al. (2014), parece não fazer sentido, não adquirindo para eles um status de inteligibilidade, o que não impede a busca do sentido.

A classe 5 do subcorpus $\mathrm{B}\left(\mathrm{B}_{2}\right)$ representa $17,53 \%(f=17 \mathrm{ST})$ do corpus total analisado. As palavras mais significativas nesta classe foram: Mais $\left(X^{2}=30,11\right)$; Molion $\left(X^{2}=24,81\right)$; Científico $\left(X^{2}=\right.$ 19,63); Cientista $\left(X^{2}=19,63\right)$; Ciência $\left(X^{2}=19,16\right)$; Bom $\left(X^{2}=08,19\right)$; Próprio $\left(X^{2}=5,17\right)$ e Efeito Estufa $\left(X^{2}=3,04\right)$. Nesta classe, a ciência e os cientistas são questionados. Prevalece a ideia de que a ciência está contaminada pela ideologia, sendo representativa dessa classe o questionamento do usuário: “Quem tá medindo??? onde está o laudo cientifico?? Quais cientistas decentes comprovam com fatos essa tese?". Prevalece ainda, a perspectiva de confronto entre os que defendem o agronegócio (e questionam a ciência) 
e os que o acusam embasados nos argumentos científicos. As associações já salientadas, servem de suporte para corroborar os argumentos. Novamente, a implicação dos sujeitos faz com que utilizem a ciência adequando-a aos seus interesses e valores, seguindo a mesma lógica anterior das associações para a Rede Globo (figura 3).

Formando a categoria $\mathrm{B}_{2.1}$ estão as classes 2 e 3. A classe 2 abarca $22,68 \%(f=22)$ do total do corpus. As palavras que se destacaram nesta classe foram: Estar $\left(X^{2}=39,33\right)$; Mundo $\left(X^{2}=17,97\right)$; Já $\left(X^{2}=\right.$ 13,42); Acabar $\left(X^{2}=10,95\right)$; Animal $\left(X^{2}=10,55\right)$; Achar $\left(X^{2}=9,88\right) ;$ Peidar $\left(X^{2}=6,51\right)$; Gás $\left(X^{2}=4,75\right)$. Parte dos segmentos de textos revelam a preocupação com a expansão agropecuária e a emissão de gases, enquanto outra parte tende a desdenhar este pensamento:

- O homem está acabando com o mundo.

- Único país do mundo que aumentou a emissão de gases sem gerar riqueza pro país [...].

- Ninguém me convence que vacas são a maior fonte de CO2 do mundo e que isso prejudica $o$ meio ambiente... sério que acham que animais peidando destróem o planeta?

- [...] animais peidam a quanto tempo? 2 ou 3 bilhões de anos. Se a destruição da Terra dependesse disso... já nem estaríamos aqui.

$\mathrm{O}$ estranhamento às descobertas científicas é claro. Porém, para alguns, não há inteligibilidade e a refutação enfática e conclusiva se torna uma possibilidade.

Já na classe $3(15,46 \%$ do corpus $-f=15)$ as palavras mais significativas foram: Agronegócio $\left(X^{2}=\right.$ 40,91); Brasileiro $\left(X^{2}=28,82\right)$; Comer $\left(X^{2}=12,83\right)$; Responsável $\left(X^{2}=11,31\right)$; Principal $\left(X^{2}=06,21\right)$. Prevalece a representação positiva do agronegócio "Amigo" -, sendo este percebido como importante para a economia e essencial para sobrevivência humana. Como destacado também no Quadro 1, os benefícios do agronegócio são lembrados:
- O Agronegócio é o principal e único responsável por termos o que comer todos os dias. \#jornalixo

- O Agronegócio foi responsável pelo pais não quebrar nestes ultimos 5 anos.

- Isso, comunistada de merda, vamos acabar com o Agronegócio, aí poderemos todos comer merda e inseto com quer a ONU! MORTE A PESTE VERMELHA!

É perceptível que não só a refutação é uma possibilidade, mas também a agressão verbal e a desqualificação, na medida em que o estranhamento e as associações feitas geram afetos de repulsa e hostilidade. Pode-se afirmar que, de uma maneira geral, as características da linguagem presente nos comentários dos usuários se assemelham à comunicação natural (clichês e frases feitas, por exemplo), que dá visibilidade as representações. Apesar de Moscovici (1979) distinguir a comunicação natural da comunicação por escrito, caracterizando-a como mais elaborada, verifica-se que, no presente caso, a comunicação apesar de digitada, se aproxima do linguajar cotidiano e natural do senso comum. É perceptível que, no contexto das redes sociais, a naturalidade e a fluidez do discurso prevalecem, sendo este acompanhado das emoções e dos afetos dos usuários, numa quase clara convergência entre o mundo virtual e real, conforme apontado por Rosa e Santos (2013).

\subsubsection{Nuvem de palavras}

No Iramuteq a Nuvem de Palavras destaca aquelas de maior importância no corpus, considerando a sua frequência (SALVIATI, 2017). A nuvem gerada (figura 4) pelo corpus analisado reforça as contradições que envolvem as RS sobre o agronegócio, colocando em xeque sua importância econômica tão ressaltada. 
Figura 4. Nuvem de Palavras.

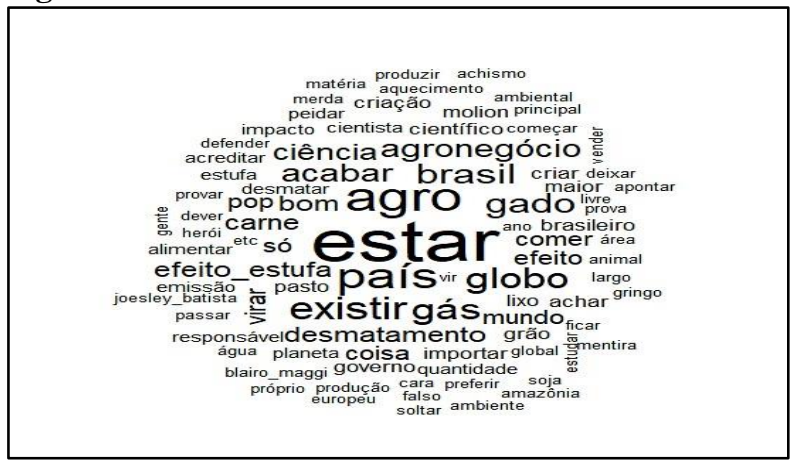

Fonte: Gerada a partir das análises textuais do Iramuteq.

Sugere, assim, que o agro é bom, é carne, é gado, é grão, é pop, é importante para o país, mas sua produção tem colocado em dúvida a possibilidade (ou a qualidade) da existência do homem em um mundo futuro. O desmatamento transforma a floresta (a Amazônia) em pasto, a emissão de gases contribui para o efeito estufa. Os usuários tentam buscar o aval da ciência, tanto para refutar quanto para corroborar com suas atitudes, mas parecem não estarem tão seguros quanto em quem ou no que acreditar.

Se academicamente o constructo agronegócio aparece muito mais como uma abstração, referindo-se à uma cadeia produtiva, à um sistema agroindustrial (ZYLBERSZTAJN; NEVES, 2000) e suas redes de relações negociais e institucionais; aqui, as associações vão objetivando-o, para uma parte do grupo pesquisado, como uma prática agropecuária predatória.

Considerando os aspectos relativos à dimensão informação das RS, destaca-se novamente a precariedade destas, apesar da abundância. Ressalta-se ainda a desconfiança naqueles que a produzem (os cientistas) e nos que a divulgam (neste caso, a Rede Globo). Se conforme Moscovici (1979), o sujeito que conhece se coloca dentro do que conhece, o momento dual e de contradições políticas afloradas parece contribuir em muito para a manutenção deste estado de precariedade e de desconfiança do que o contrário.

\section{CONSIDERAÇÕES FINAIS}

Objetivou-se com este estudo investigar as RS sobre o agronegócio a partir de opiniões expressas por usuários da rede social Facebook. A empreitada delineada para tal não se constituiu em um caminho fácil. A busca do entendimento científico, diferente das RS, não permite contentar-se com a associação primeira ou que se faz atrativa aos interesses pessoais ou de um grupo. O confronto com a teoria, a busca, ainda que precária, de um distanciamento se fazem necessários.

Moscovici (1979) revelou em seu estudo que as representações nem sempre são claras e objetivas, a contradição, a desorganização e a plasticidade lhes são características. Os sujeitos, na busca da apropriação do conhecimento, mesclam imagens, vocábulos, signos e símbolos que dispõem. O assombro diante das descobertas da ciência leva às tentativas de incorporálas ao seu universo (o conhecido), mesclando, unindo com o dispõem de conhecimento, de capacidade de interpretação. Neste caminho, os indivíduos transformam este conhecimento para conformar aos seus marcos referenciais internalizados, aos seus interesses e valores.

\section{Considerando essas características na} elaboração das RS, constatou-se, também no presente estudo, essa desorganização e contradição, bem como a plasticidade em termos de associações feitas. Elas vão se encaixando aos interesses e visões dos indivíduos. Não obstante, em função da precariedade dos argumentos, os adjetivos desqualificadores, as proposições conclusivas e clichês são utilizados.

Ao que tudo indica, aquilo que foi apontado por Cappellesso e Guimarães (2016) e Cappellesso, Guimarães e Carvalho (2019) também prevalece aqui, ou seja, o agronegócio é associado à produção agropecuária em escala, tanto pelos que lhes são favoráveis quanto pelos que lhes são desfavoráveis. Para estes últimos, o agronegócio aparece associado à 
direita, aos empresários capitalistas, à grande mídia, aos políticos ruralistas, aos que desmatam... e as associações prosseguem em um quase ad eternum.

Observa-se que as representações desvelam posições marcadamente polarizadas reforçando separações ideológicos e potencializadoras de conflitos. Posições que não contribuem para equilibrar as relações de poder no âmbito da coordenação das diferentes cadeias produtivas. Não obstante, entendese que tais representações, histórica e socialmente construídas (SANTOS; ICHIKAWA, 2018), relacionam-se também à atuação dos agentes do setor incorporadas à memória coletiva dos diferentes grupos.

Moscovici (1979) citando Hegel afirma que todo racional é real, porque este é forçado a se conformar com o racional. Neste jogo cognitivo, a realidade parece importar cada vez menos, reforçando crenças e preconceitos. Tudo isso demonstra a importância de ações coordenadas e estratégicas por aqueles que atuam no setor (profissionais de gestão de agronegócios, acadêmicos, pesquisadores, empresários, dentre outros). Revela ainda necessidade de uma atuação ética, transparente e responsável a fim de, paulatina e positivamente, transformar o modo como o agronegócio é representado pelos diferentes grupos sociais.

Sem desconsiderar as limitações do presente estudo - o fato de restringir-se a uma matéria específica, de um veículo de comunicação específico - acredita-se em sua contribuição no sentido de aclarar um pouco mais as RS sobre o objeto social aqui investigado - o agronegócio - este, raramente investigado dentro da abordagem teórica aqui adotada. Ele avança em relação aos estudos já citados expandindo sua amostra para além do ambiente universitário e identificando mais fortemente as atitudes em relação ao agronegócio.
Como agenda para estudos futuros, recomenda-se o aprofundamento na compreensão mecanismos de ancoragem e objetivação nas RS sobre o agronegócio bem como a expansão do estudo para diferentes grupos sociais.

Todos os autores declararam não haver qualquer potencial conflito de interesses referente a este artigo.

\section{REFERÊNCIAS}

ABAG. A percepção da população dos grandes centros urbanos sobre o agronegócio brasileiro. 2013. Disponível em:

http://www.abag.com.br/en/media/analise-abagnacional.pdf. Acesso em: 22 jul. 2019.

BARDIN, L. Análise de conteúdo. Lisboa: Edições $70,1977$.

BARBOSA, C.; SOUSA, J. P. Comunicação da ciência e redes sociais: um olhar sobre o uso do Facebook na divulgação científica. In: PIRES, H. et al.(ed.). Cibercultura: circum-navegações em redes transculturais de conhecimento, arquivos e pensamento. Famalicão: Húmus, 2017. p. 279-289. Ebook.

BRANCO, M. Produção de grãos deve aumentar e chegar a 202 milhões de toneladas, diz Conab.

Agência Brasil. Brasília, 09 jan. 2015. Economia. Disponível em:

http://agenciabrasil.ebc.com.br/economia/noticia/201 5-01/producao-de-graos-aumenta-45-e-chega-202milhoes-de-toneladas-diz-conab. Acesso em: $21 \mathrm{abr}$. 2019.

BUAINAIN, A. M. et al. Sete teses sobre o rural brasileiro. In: BUAINAIN, A. M. et al. (org.). $\mathbf{O}$ mundo rural no século 21: a formação de um novo padrão agrário e agrícola. Brasília, DF: EMBRAPA, 2014. anexo. p.1160-1182.

\section{CAMARGO, B. V.; JUSTO, A. M. Tutorial para uso do software de análise textual Iramuteq. Santa Catarina: Universidade Federal de Santa Catarina. 2013. Disponível em \\ http://www.iramuteq.org/documentation/fichiers/tutor iel-en-portugais. Acesso em: 10 ago. 2019.}

CASTELLS, M. A sociedade em rede: do conhecimento à política. In: CASTELLS, M; CARDOSO, G. (org.). A sociedade em rede: do conhecimento à acção política. Lisboa: Imprensa Nacional. 2005. p. 17-30. E-book. 
CAPPELLESSO, G.; GUIMARÃES, M. C. O conceito de agronegócios e suas representações sociais: um estudo com estudantes do curso de gestão de agronegócios. In: PRE-CONGRESO ALASRU, 2016, Santiago del Estero. Libro de Ponencias [...] Santiago del Estero: UNSE, 2016. p.745-764.

CAPPELLESSO, G.; GUIMARÃES, M. C.; CARVALHO, J. M. Representações sociais sobre 'agronegócios': um estudo com discentes de curso ligado à sua gestão. In: CONGRESSO DA SOCIEDADE BRASILEIRA DE ECONOMIA, ADMINISTRAÇÃO E SOCIOLOGIA RURAL, 57.,2019, Ilhéus. Anais [...]. Brasília: SOBER, 2019. Disponível em:

https://icongresso.itarget.com.br/useradm/anais/?clt=s er.9\&lng=P. Acesso em: 12 mar. 2019.

CAUME, D. J. Agricultura familiar e agronegócio: falsas antinomias. Redes, v. 14. n. 1. p. 26-44, 2009.

CEPEA. PIB-AGRO/CEPEA: PIB do agronegócio fecha 2018 com estabilidade. 2018. Disponível em: https://www.cepea.esalq.usp.br/br/releases/pib-agrocepea-pib-do-agronegocio-fecha-2018-comestabilidade.aspx. Acesso em: 08 abr. 2019.

CHOW, T. S.; WAN, H. Y. Is there any 'Facebook Depression'? Exploring the moderating roles of neuroticism, Facebook social comparison and envy. Personality and Individual Differences, v. 119, n.1, p. 277-282, 2017.

CILO, N. Agronegócio e comércio devem puxar PIB em 2020. Estado de Minas, Belo Horizonte, 09 jan. 2020, Economia. Disponível em: https://www.em.com.br/app/noticia/economia/2020/0 1/09/internas_economia,1113093/agronegocio-ecomercio-devem-puxar-pib-em-2020.shtml. Acesso em: 15 jan. 2020.

\section{CLEMENT, J. Most popular social networks} worldwide as of April 2019, ranked by number of active users (in millions). 2019. Disponível em: https://www.statista.com/statistics/272014/globalsocial-networks-ranked-by-number-of-users/

CUNHA, G. O fio da meada. In: PORTO, S. D. (org.). Sexo, afeto e era tecnológica: um estudo de chats na internet. Brasília: Editora UnB, 1999. p. 101123.

FAVARETO, A. (coord.). Entre baixadas e baixões do MATOPIBA: dinâmicas territoriais e impactos socioeconômicos na fronteira da expansão agropecuária no Cerrado. São Paulo: Prefixo Editorial, 2019. E-book.
GASQUES, J. G. et al. Desempenho e crescimento do agronegócio no Brasil. Brasília: IPEA. 2004. (Texto para discussão no. 1009).

GERHARDT, T. E.; SILVEIRA, D. T. Métodos de pesquisa. Porto Alegre: Editora da UFRGS, 2009.

HAJE, L.; ATTUCH, M. O discurso da sexualidade nos chats. In: PORTO, S. D. (org.). Sexo, afeto e era tecnológica: um estudo de chats na internet. Brasília: Editora UnB, 1999. p. 81-99.

JODELET, D. Représentations sociales: un domaine en expansion. Tradução T. B. Mazzotti e revisão técnica A. J. Alves-Mazzotti. In: JODELET, D. (ed.) Les représentations sociales. Paris: PUF, 1989. p. 31-61. Disponível em https://www.researchgate.net/publication/324979211 _Representacoes_sociais_Um_dominio_em_expansa o. Acesso em: 05 jun. 2019.

JOO, T.-M.; TENG, C.-E. Impacts of social media (Facebook) on humancommunication and relationships: a view on behavioral change and social unity. International Journal of Knowledge Content Development \& Technology, v. 7, n. 4, p. 27-50, 2017.

KOZINETS, R. V. The field behind the screen: using netnography for marketing research in online communities. Journal of Marketing Research, v. 39, p. 61-72. 2002.

LINS, C. F. M. Apostila de Iramuteq. Manuscrito não publicado. Fortaleza, CE: Programa de Pósgraduação em Psicologia da Universidade de Fortaleza, [201-].

MARQUES, L. K. S.; VIDIGAL, F. Prosumers e redes sociais como fontes de informação mercadológica: uma análise sob a perspectiva da inteligência competitiva em empresas brasileiras. TransInformação, v. 30, n. 1, p. 1-14, 2018.

MESQUITA, R. F. de; MATOS, F. R. N.; MACHADO, D. Q. Do espaço ao ciberespaço: sobre etnografia e netnografia. Perspectivas em Ciên. da Inf., v. 23, n. 2, p. 146-165, 2018.

MORA, M. La teoría de las representaciones sociales de Serge Moscovici. Athenea Digital, n. 2. p. 1-25, 2002. Disponível em https://atheneadigital.net/article/view/n2-mora. Acesso em: 20 maio 2019.

MOSCOVICI, S. El psicoanálisis, su imagen y su público. Buenos Aires: Editorial Huemul, 1979. MST. Sem Terra vão às ruas na Jornada de Lutas pela Reforma Agrária 2015. [ $\left.\begin{array}{ll}S . & l .]\end{array}\right] 17$ abr. 2015. 
Disponível

em:

http://www.mst.org.br/2015/04/09/vivemos-umnovo-momento-da-luta-social-e-politica-no-brasilonde-a-luta-de-classes-agoniza-e-expoe-ascontradicoes-da-nossa-sociedade.html. Acesso em: 19 abr. 2019.

O GLOBO. Agronegócio é apontado como o principal responsável pela emissão de poluente. Facebook: @jornaloglobo. 2017. Disponível em: https://www.Facebook.com/search/top/?q=Emiss\%C 3\%A3o\%20de\%20gases\%20do\%20efeito\%20estufa $\% 20$ no\%20Brasil\%20cresce $\% 209 \% 25 \% 20$ em $\% 2020$ $16 \%$ E2\%80\%9D\&epa=SEARCH_BOX. Acesso em: 10 maio 2019.

PORTO, S. D. (org.). Sexo, afeto e era tecnológica: um estudo de chats na internet. Brasília: Editora UnB, 1999.

RECUERO, R. C. Elementos para a análise da conversação na comunicação mediada pelo computador. Verso e Reverso, v. 22, n. 51, 2008.

RIBEIRO, J. C.; AYRES, M. Breves comentários sobre a análise de conversações em sites de redes sociais. In: PORTO, C.; SANTOS, E. (org.).

Facebook e educação: publicar, curtir, compartilhar. Campina Grande: EDUEPB, 2014. p.199-220. Ebook.

ROSA, G. A. M.; SANTOS, B. R. Facebook e as nossas identidades virtuais. Brasília: Thesaurus, 2013.

SÁ, C. P. Representações sociais: o conceito e o estado atual da teoria: In: SPINK, M. J. (org.). $\mathbf{O}$ conhecimento cotidiano: as representações sociais na perspectiva da psicologia social. São Paulo: Brasiliense, 1993. cap. 1. p. 19-45.

SACCHITIELLO, B. Circulação digital dos grandes jornais cresce no Brasil. Meio \& Mensagem. 2019. Disponível em:

https://www.meioemensagem.com.br/home/midia/20 19/01/30/circulacao-digital-dos-grandes-jornaiscresce-no-brasil.html. Acesso em: 30 maio 2019.

SALVIATI, M. E. Manual do aplicativo Iramuteq. Planaltina, 2017. Disponível em http://www.iramuteq.org/documentation/fichiers/man ual-do-aplicativo-iramuteq-par-maria-elisabethsalviati. Acesso em: 10 ago. 2019.

SANTOS, V. T. dos; ICHIKAWA, E. Y.

Representações sociais, história e memória: possíveis contribuições para os estudos organizacionais.

Revista Gestão e Sociedade, Belo Horizonte, v. 12, n. 31, p. 2213-2231, 2018.

SHIRKY, C. A cultura da participação:

criatividade e generosidade no mundo conectado. Rio de Janeiro: Zahar, 2011. E-book.

SILVA, P. B. da; GUIMARÃES, M. C. O conceito de agronegócios e suas representações na mídia brasileira. In: PRE-CONGRESO ALASRU, 2016, Santiago del Estero. Libro de Ponencias [...] Santiago del Estero: UNSE, 2016. p. 819-837.

SÜLFLOW, M.; SCHÄFER, S.; WINTER, S Selective attention in the news feed: an eye-tracking study on the perception and selection of political news posts on Facebook. New Media \& Society, v. 21, n. 1, p. 168-191, 2019.

TEIXEIRA, D.; AZEVEDO, I. Análise de opiniões expressas nas redes sociais. RISTI - Revista Ibérica de Sistemas e Tecnologias de Informação, (8), 5365. 2011.

VEPSÄLÄINEN, T.; LI, H.; SUOMI, R. Facebook likes and public opinion: predicting the 2015 Finnish parliamentary elections. Gov. Inf. Quarterly, v. 34, n. 3, p. 524-533, 2017.

WELLE, D. Agropecuária é responsável por $90 \%$ do desmatamento ilegal no Brasil. Carta Capital. São Paulo, 16 set. 2014. Sustentabilidade.

WILKINSON, J. Transformações e perspectivas dos agronegócios brasileiros. Revista Brasileira de Zootecnia, Viçosa, v. 39, p. 26-34, 2010. Supl. Especial.

ZYLBERSZTAJN, D.; NEVES, M. F. Economia e gestão dos negócios agroalimentares. São Paulo: Pioneira, 2000. 